\title{
SAMESTELLER SE VOORWOORD
}

Die opdrag om 'n oorsig te skryf van die honderd jaar waarin die Kuratorium vir die Teologiese Opleiding van die Nederduitsch Hervormde Kerk van Afrika sy opgelegde taak probeer uitvoer het, het vereis dat ' $n$ bepaalde minimum literatuur in ag geneem moes word. Dit het onder andere behels die notules en dokumente van die Kuratorium, die Kommissie van die Algemene Kerkvergadering, die Algemene Kerkvergadering, die Raad en Senaat en Fakulteit Teologie van die Universiteit van Pretoria, en die Vergadering van Professore, later die Dosentevergadering, oor die tydperk 1909-2009. Al hierdie notules is beskikbaar in die Argiefbewaarplekke van die Nederduitsch Hervormde Kerk en die Universiteit van Pretoria. Daarby het gekom kerklike en universitêre tydskrifte. Ander bronne wat hier nie in ag geneem is nie, is die notules en ander dokumente van kerklike organe van bystand

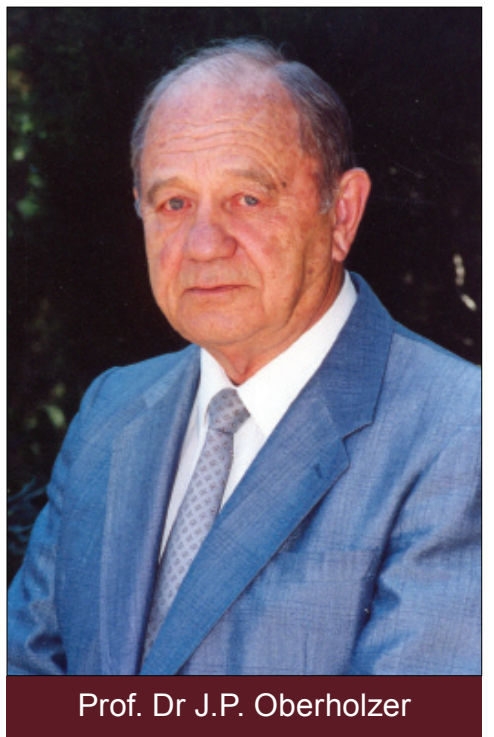

en rade. In wat volg, is oor die algemeen hierdie (en ander) bronne self aan die woord gestel en is kommentaar tot ' $\mathrm{n}$ minimum beperk (tussen vierkante hakies.

Die aanbieding in die vorm van ' $\mathrm{n}$ kroniek het met verloop van tyd homself aan die orde gestel. Die Indeks wat bygevoeg is, kan dien as sleutel vir tematisering vir wie ookal dit nodig vind.Die lys van persone wat die teologiese studie voltooi het, is bedoel om insig te gee in die resultate van die eeu se werksaamheid. Daarnaas bied die lys van persone wat nie die studie afgehandel het nie, die versoberende en al te menslike beeld van onvervulde voornemens en verlies van tyd en geld, of soms ook verandering van rigting.

Aan die Kuratorium my dank vir die opdrag om hierdie taak uit te voer, aan die personeel van die Kerk- en Universiteitsargiewe my hartlike dank vir vriendelike diens.

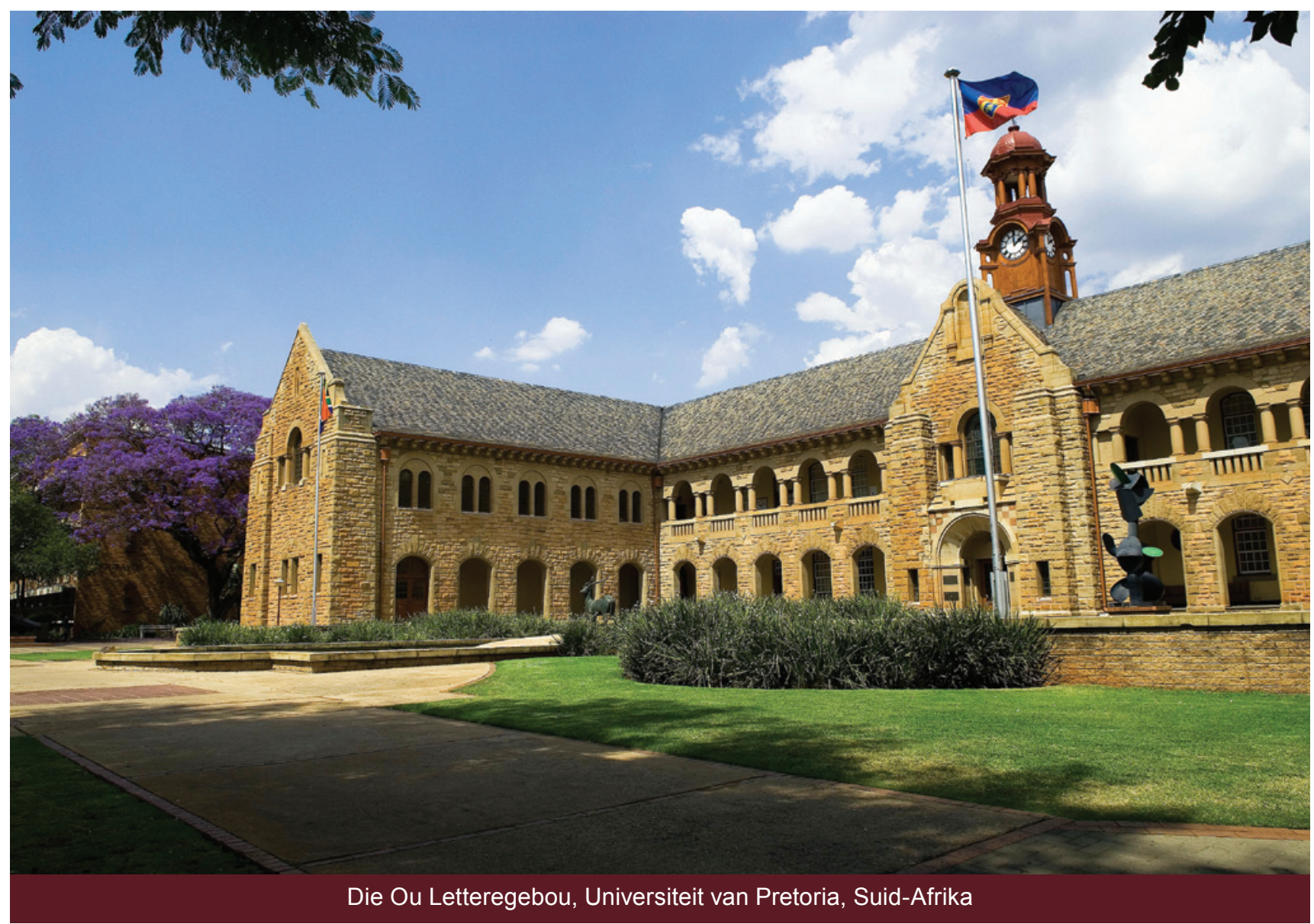

Sitasie: Oberholzer, J.P., 2010, 'Samesteller se voorwoord', in 'Honderd Jaar Kerk en Teologiese Opleiding: 'n Kroniek van die Hervormde Kerk', HTS Teologiese Studies/Theological Studies, suppl. 9, 66(3), Art. \#942, 1 page. DOI: 10.4102/hts.v66i3.942 